\title{
STUDI DESKRIPTIF PENGGUNAAN METODE KONTRASEPSI DI PMB ANIK SETYOWATI NGESREP NGEMPLAK BOYOLALI
}

\author{
Contraception Method Uses Descriptive Study in Anik Setyowati Midwife \\ at Ngesrep Ngemplak Boyolali \\ Anita Dewi Lieskusumastuti ${ }^{1}$, Catur Setyorini ${ }^{2}$ \\ STIKES Mamba'ul 'Ulum Surakarta \\ (anita.dewi712@yahoo.co.id)
}

\begin{abstract}
ABSTRAK
Latar Belakang: Peserta Keluarga Berencana aktif di antara pasangan usia subur tahun 2017 di Indonesia sebesar 63,22\%, sedangkan yang tidak pernah menggunakan kontrasepsi sebesar $18,63 \%$. Berdasarkan pola pemilihan alat kontrasepsi, sebagian besar peserta KB Aktif memilih suntikan dan pil sebagai alat kontrasepsi bahkan sangat dominan (lebih dari 80\%) dibanding metode lainnya; suntik $(62,77 \%)$ dan pil $(17,24 \%)$. Pemilihan metode KB oleh akseptor berkaitan dengan faktor perilaku masing-masing individu. Praktik Bidan memberikan pelayanan paling banyak yaitu sebesar $60,42 \%$ dari jumlah PUS yang dilayani oleh jejaring. Penelitian ini bertujuan untuk mengetahui penggunaan metode kontrasepsi di PMB Anik Setyowati Ngesrep Ngemplak Boyolali.

Metode: Penelitian ini menggunakan metode observasional deskriptif dengan pendekatan potong lintang. Populasi penelitian ini adalah semua wanita pasangan usia subur yang melakukan kunjungan KB di PMB Anik Setyowati Ngesrep Ngemplak Boyolali Tahun 2018. Teknik pengambilan sampel yang digunakan adalah Accidental Sampling. Alat pengumpulan datanya adalah kuesioner. Analisa data menggunakan analisis univariat yakni distribusi frekuensi.

Hasil: Hasil penelitian berjudul Studi Deskriptif Penggunaan Metode Kontrasepsi di PMB Anik Setyowati Ngesrep Ngemplak Boyolali didapatkan sebagian besar responden berumur 20-35 tahun sebanyak 24 responden $(72,7 \%)$; dengan pendidikan Sedang dan rendah, masing-masing sebanyak 16 responden $(48,5 \%)$; bekerja sebanyak 21 responden $(63,6 \%)$. Sebagian besar responden menggunakan Non Metode Kontrasepsi Jangka Panjang (Non MKJP) sebanyak 25 responden (75,8\%), yakni Kontrasepsi Suntik sebanyak 18 responden $(54,6 \%)$.
\end{abstract}

Simpulan: Sebagian besar responden berumur 21-35 tahun, berpendidikan sedang dan rendah, bekerja, menggunakan metode kontrasepsi Non MKJP yakni Suntikan kontrasepsi.

Kata Kunci: Umur, Pendidikan, Pekerjaan, Metode Kontrasepsi

\section{ABSTRACT}

Background: Family Planning Participants active among couples of childbearing age in 2017 in Indonesia amounted to 63.22\%, while those who never used contraception were $18.63 \%$. Based on the pattern of contraceptive selection, most Active acceptors choose injections and pills as contraceptives and are even more 
dominant (more than $80 \%$ ) compared to other methods; injections $(62.77 \%)$ and pills (17.24\%). The choice of contraception method by acceptors is related to the behavioral factors of each individual. Midwives' practices provide the most services, amounting to $60.42 \%$ of the number of fertile age couples served by the network. This study aims to determine the use of contraceptive methods in Anik Setyowati Midwife Ngesrep Ngemplak Boyolali.

Method: This study used a descriptive observational method with a cross sectional approach. The population of this study were all women of childbearing age who made a family planning visit in Anik Setyowati Ngesrep Midwife Ngemplak Boyolali in 2018. The sampling technique used was accidental sampling. The data collection tool is a questionnaire. Data analysis using univariate analysis, namely frequency distribution.

Results: The results of the study entitled Descriptive Study of the Use of Contraceptive Methods in Anik Setyowati Ngesrep Midwife Ngemplak Boyolali found that the majority of respondents aged 20-35 years were 24 respondents (72.7\%); with moderate and low education, each of them was 16 respondents (48.5\%); work as many as 21 respondents (63.6\%). Most of the respondents used Non-Long Term Contraceptive Method (Non MKJP) as many as 25 respondents (75.8\%), ie Injection Contraception as many as 18 respondents (54.6\%).

Conclusion: Most of the respondents aged 21-35 years, have moderate and low education, work, use non MKJP contraceptive methods, namely contraceptive injections.

Keywords: Age, Education, Occupation, Contraception Method

\section{PENDAHULUAN}

Kepadatan penduduk di Indonesia belum merata, dalam hal ini kepadatan penduduk berguna sebagai pedoman dalam mewujudkan pemerataan dan persebaran penduduk. Berdasarkan hasil estimasi rata-rata kepadatan penduduk di Indonesia tahun 2017 sebesar 136,86 jiwa per $\mathrm{km}^{2}$, keadaan ini meningkat dari tahun sebelumnya sebesar 135,19 jiwa per $\mathrm{km}^{2}$. Pemerintah Indonesia melaksanakan beberapa cara untuk pemerataan penduduk, salah satunya pengendalian jumlah penduduk dengan menurunkan jumlah kelahiran melalui program keluarga berencana $(\mathrm{KB})$ atau penundaan umur pernikahan pertama. (Kemenkes RI, 2018)

Peraturan Pemerintah Indonesia Nomor 87 tahun 2014 tentang Kependudukan dan Pembangunan Keluarga, Keluarga Berencana dan Sistem Informasi Keluarga menyebutkan bahwa program KB adalah upaya mengatur kelahiran anak, jarak dan usia ideal melahirkan, mengatur kehamilan, melalui promosi, perlindungan dan bantuan sesuai dengan hak reproduksi untuk mewujudkan keluarga yang berkualitas. (Kemenkes RI, 2018)

Peserta Keluarga Berencana aktif di antara Pasangan Usia Subur (PUS) tahun 2017 di Indonesia sebesar 63,22\%, sedangkan yang tidak pernah menggunakan kontrasepsi sebesar $18,63 \%$. Berdasarkan pola pemilihan alat kontrasepsi, sebagian besar peserta KB Aktif memilih suntikan dan pil sebagai alat kontrasepsi bahkan sangat dominan (lebih dari 80\%) dibanding metode lainnya; suntik 
$(62,77 \%)$ dan pil $(17,24 \%)$. Padahal KB suntik dan pil merupakan metode kontrasepsi jangka pendek sehingga tingkat efektivitasnya dalam pengendalian kehamilan lebih rendah dibandingkan kontrasepsi lainnya. (Kemenkes RI, 2018)

Status pemakaian kontrasepsi dan jenis kontrasepsi yang dipakai wanita dengan status kawin rentang usia 15-49 tahun di Indonesia pada tahun 2017 yaitu tidak pakai alat atau cara KB sebesar 36,4\% dan Pakai Alat atau Cara KB sebesar 63,6\%). (BKKBN, 2018)

Partisipasi laki-laki dalam menggunakan kontrasepsi masih sangat rendah yaitu pada MOP sebesar 0,53\% dan kondom sebanyak 1,22\%. Penggunaan MKJP (Metode Kontrasepsi Jangka Panjang) masih sangat rendah dikarenakan pengetahuan masyarakat yang masih rendah tentang kelebihan metode MKJP dan keterbatasan jumlah tenaga terlatih serta sarana yang ada. Dari keseluruhan jumlah peserta KB aktif di Indonesia tahun 2017 hanya 17,45\% diantaranya yang menggunakan KB MKJP. Sedangkan 81,23\% lainnya pengguna KB non MKJP dan 1,32\% menggunakan KB tradisional. (Kemenkes RI).

Cakupan peserta KB aktif pada tahun 2015 di Kabupaten Boyolali sebesar 80\% dari total Pasangan Usia Subur (PUS) 171.119 yang ada. Target nasional untuk peserta KB baru sebesar 80\%. Cakupan peserta KB baru tahun 2015 di Kabupaten Boyolali sebanyak 18.755 ( 10,96\% ) dari jumlah PUS yang ada yaitu 171.119. Sebagian besar Peserta KB baru di Kabupaten Boyolali tahun 2015 menggunakan kontrasepsi Non Metode Kontrasepsi Jangka Panjang / Non MKJP sebanyak 61,8\% dan sebagian lagi menggunakan Metode Kontrasepsi Jangka Panjang / MKJP sebanyak 38,2\%. MKJP antara lain AKDR (15,1\%), MOP $(0,1 \%)$, MOW (4\%), AKBK (19\%). Non MKJP antara lain suntik $(55,4 \%)$, pil $(4,1 \%)$, kondom (2,4\%). (Kab. Boyolali, 2016)

Program Keluarga Berencana memberikan dampak yaitu penurunan angka kematian ibu dan anak; penanggulangan masalah kesehatan reproduksi; peningkatan kesejahteraan keluarga; peningkatan derajat kesehatan; peningkatan mutu dan layanan Keluarga Berencana- Kesehatan Reproduksi; peningkatan system pengelolaan dan kapasitas SDM; pelaksanaan tugas pimpinan dan fungsi manajemen dalam penyelenggaraan kenegaraan dan pemenrintahan berjalan lancar. (Anggraeni, 2017)

KB juga merupakan salah satu cara paling efektif untuk meningkatkan ketahanan keluarga, kesehatan, dan keselamatan ibu, anak serta perempuan. Pelayanan KB meliputi penyediaan informasi, pendidikan dan cara-cara bagi keluarga untuk dapat merencanakan kapan akan mempunyai anak, berapa jumlah anak, berapa tahun jarak usia antara anak, serta kapan akan berhenti mempunyai anak. (Kemenkes RI, 2018)

Pemilihan metode KB oleh akseptor berkaitan dengan faktor perilaku masingmasing individu. Perilaku dipengaruhi oleh tiga faktor berdasarkan teori Perilaku Lawrence Green (2005). Faktor yang pertama predisposing factor merupakan faktor pemudah atau mempredisposisikan terjadinya perilaku seseorang yang dapat dilihat dari umur, pendidikan, pengetahuan, sikap, paritas dan riwayat kesehatan. Faktor yang kedua adalah enabling factor atau faktor pemungkin yaitu faktor yang memungkinkan atau memfasilitasi perilaku atau tindakan, faktor ini meliputi Pelayanan KB (ruangan, alat, dan transportasi). Faktor ketiga adalah 
reinforcing factor atau faktor penguat yaitu faktor yang memperkuat terjadinya perilaku, dalam hal ini adalah dukungan suami dan dukungan petugas pelayanan KB (Setiasih, 2016)

Berdasarkan hasil penelitian Setiasih menunjukkan Sebagian besar wanita PUS yang ada di Kabupaten Kendal memilih alat kontrasepsi MKJP Hormonal yaitu sejumlah 296 responden $(71,5 \%)$ dan sebagian kecil memilih MKJP Non Hormonal yaitu sejumlah 114 responden (28,5\%). Faktor yang paling berpengaruh dalam pemilihan Metode Kontrasepsi Jangka Panjang di Kabupaten Kendal adalah faktor sikap. Selain sikap, faktor yang berpengaruh secara berurutan adalah pengetahuan, ketersediaan layanan $\mathrm{KB}$, dan dukungan petugas pelayanan KB. (Setiasih, 2016)

Berdasarkan studi pendahuluan di PMB Anik Setyowati pada bulan JanuariMaret 2018 didapatkan jumlah akseptor KB Lama sebesar 285 PUS dan akseptor baru sebesar 24 PUS. Sasaran program KB yaitu Pasangan Usia Subur (PUS). Pasangan Usia Subur adalah pasangan suami istri yang terikat dalam perkawinan sah dan istrinya berumur antara 15 sampai 49 tahun. (Kemenkes RI, 2018)

Tempat pelayanan KB di Indonesia tahun 2017 paling banyak oleh Jejaring sebesar 56,19\%. Jejaring tersebut terdiri atas Pusksmas Pembantu/Puskesmas Keliling/Bidan Desa, Poskesdes/Polindes dan Praktik Bidan. Praktik Bidan memberikan pelayanan paling banyak yaitu sebesar $60,42 \%$ dari jumlah PUS yang dilayani oleh jejaring. (Kemenkes RI, 2018)

Berdasarkan uraian diatas maka peneliti tertarik untuk melakukan penelitian yang berjudul Studi Deskriptif Penggunaan Metode Kontrasepsi Di PMB Anik Setyowati Ngesrep Ngemplak Boyolali. Tujuan Penelitian ini adalah untuk mengetahui penggunaan metode kontrasepsi di PMB Anik Setyowati Ngesrep Ngemplak Boyolali.

\section{METODE PENELITIAN}

Penelitian ini merupakan penelitian observasional bersifat deskriptif dengan pendekatan potong lintang. Populasi penelitian ini adalah semua wanita pasangan usia subur yang melakukan kunjungan KB di PMB Anik Setyowati Ngesrep Ngemplak Boyolali Tahun 2018. Teknik pengambilan sampel yang digunakan adalah Accidental Sampling. Sampel dalam penelitian ini adalah sebagian wanita pasangan usia subur yang melakukan kunjungan KB di PMB Anik Setyowati Ngesrep Ngemplak Boyolali yang ditemui peneliti pada bulan April Tahun 2018 sebanyak 33 responden.

Alat pengumpulan data yang digunakan dalam penelitian ini adalah kuesioner. Metode pengumpulan data yang digunakan adalah pengumpulan data primer dan sekunder. Data-data yang sudah terkumpul kemudian dilakukan pengolahan data meliputi Editing, Coding, Tabulating dan Entering. Analisa data dalam penelitian ini menggunakan analisis univariat. Analisis univariat menggunakan distribusi frekuensi. 


\section{Hasil Penelitian}

\section{HASIL DAN PEMBAHASAN}

Hasil dari analisis distribusi frekuensi, diperoleh data umur, pendidikan, pekerjaan, metode kontrasepsi dan jenis-jenis kontrasepsi responden yang melakukan kunjungan KB di PMB Anik Setyowati periode April 2018. Berikut distribusi frekuensi umur reponden yang disajikan pada tabel-tabel dibawah ini:

Tabel 1 Distribusi Frekuensi Umur Responden di PMB Anik Setyowati Ngesrep Ngemplak Boyolali

\begin{tabular}{lcc}
\hline \multicolumn{1}{c}{ Umur } & Frekuensi & Perseentas $(\%)$ \\
\hline$<20$ tahun & 1 & 3 \\
$21-35$ tahun & 24 & 72,7 \\
$>35$ tahun & 8 & 24,2 \\
Total & 33 & 100 \\
\hline
\end{tabular}

Berdasarkan Tabel 1 diketahui bahwa sebagian besar responden yang berumur 20-35 tahun sebanyak 24 responden $(72,7 \%)$.

Tabel 2 Distribusi Frekuensi Pendidikan Responden di PMB Anik Setyowati Ngesrep Ngemplak Boyolali

\begin{tabular}{lcc}
\multicolumn{1}{c}{ Pendidikan } & Frekuensi & Persentase $(\%)$ \\
\hline Tinggi & 1 & 3 \\
Sedang & 16 & 48,5 \\
Rendah & 16 & 48,5 \\
Total & 33 & 100 \\
\hline
\end{tabular}

Berdasarkan Tabel 2 diketahui bahwa sebagian besar responden yang dengan pendidikan Sedang dan rendah, masing-masing sebanyak 16 responden $(48,5 \%)$.

Tabel 3 Distribusi Frekuensi Pekerjaan Responden di PMB Anik Setyowati Ngesrep Ngemplak Boyolali

\begin{tabular}{lcc}
\hline \multicolumn{1}{c}{ Pekerjaan } & Frekuensi & Persentase (\%) \\
\hline Bekerja & 21 & 63,6 \\
Tidak Bekerja & 12 & 36,4 \\
Total & 33 & 100
\end{tabular}

Berdasarkan Tabel 3 diketahui bahwa sebagian besar responden bekerja sebanyak 21 responden $(63,6 \%)$.

Tabel 4 Distribusi Frekuensi Penggunaan Metode Kontrasepsi Berdasarkan Jangka Waktu di PMB Anik Setyowati Ngesrep Ngemplak Boyolali

\begin{tabular}{|c|c|c|}
\hline Metode Kontrasepsi & Frekuensi & Persentase (\%) \\
\hline MKJP & 8 & 24,2 \\
\hline NON MKJP & 25 & 75,8 \\
\hline Total & 33 & 100 \\
\hline
\end{tabular}

Berdasarkan Tabel 4 diketahui bahwa sebagian besar responden menggunakan Non Metode Kontrasepsi Jangka Panjang (Non MKJP) sebanyak 25 responden $(75,8 \%)$. 
Tabel 5 Distribusi Frekuensi Jenis-Jenis Kontrasepsi Responden di PMB Anik Setyowati Ngesrep Ngemplak Boyolali

\begin{tabular}{lcc}
\hline \multicolumn{1}{c}{ Jenis-Jenis Kontrasepsi } & Frekuensi & Persentase (\%) \\
\hline Kondom & 1 & 3 \\
MAL & 2 & 6,1 \\
Suntik & 18 & 54,6 \\
Pil & 4 & 12,1 \\
AKDR & 4 & 12,1 \\
AKBK & 4 & 12,1 \\
Total & 33 & 100 \\
\hline
\end{tabular}

Berdasarkan Tabel 5 diketahui bahwa sebagian besar responden menggunakan Kontrasepsi Suntik sebanyak 18 responden $(54,6 \%)$.

Tabel 6 Tabulasi Silang Umur Responden dan Metode Kontrasepsi di PMB Anik Setyowati Ngesrep Ngemplak Boyolali

\begin{tabular}{lccc}
\hline \multirow{2}{*}{ Umur } & \multicolumn{2}{c}{ Metode Kontrasepsi } & Total \\
\cline { 2 - 3 } & MKJP & Non MKJP & \\
\hline$<20$ tahun & $0(0 \%)$ & $1(3 \%)$ & $1(3 \%)$ \\
$21-35$ tahun & $5(15,2 \%)$ & $19(57,6 \%)$ & $24(72,7 \%)$ \\
$>35$ tahun & $3(9,1 \%)$ & $5(15,2 \%)$ & $8(24,2 \%)$ \\
Total & $8(24,2 \%)$ & $25(75,8 \%)$ & $33(100 \%)$ \\
\hline
\end{tabular}

Tabel 7 Tabulasi Silang Pendidikan Responden dan Metode Kontrasepsi di PMB Anik Setyowati Ngesrep Ngemplak Boyolali

\begin{tabular}{|c|c|c|c|}
\hline \multirow[t]{2}{*}{ Umur } & \multicolumn{2}{|c|}{ Metode Kontrasepsi } & \multirow[t]{2}{*}{ Total } \\
\hline & MKJP & Non MKJP & \\
\hline Tinggi & $0(0 \%)$ & $1(3 \%)$ & $1(3 \%)$ \\
\hline Sedang & $4(12,1 \%)$ & $12(36,4 \%)$ & $16(48,5 \%)$ \\
\hline Rendah & $4(12,1 \%)$ & $12(36,4 \%)$ & $16(48,5 \%)$ \\
\hline Total & $8(24,2 \%)$ & $25(75,8 \%)$ & $33(100 \%)$ \\
\hline
\end{tabular}

Tabel 8 Tabulasi Silang Pekerjaan Responden dan Metode Kontrasepsi di PMB Anik Setyowati Ngesrep Ngemplak Boyolali

\begin{tabular}{lccc}
\hline \multirow{2}{*}{ Umur } & \multicolumn{2}{c}{ Metode Kontrasepsi } & Total \\
\cline { 2 - 3 } & MKJP & Non MKJP & \\
\hline Bekerja & $3(9,1 \%)$ & $18(54,5 \%)$ & $21(63,6 \%)$ \\
Tidak Bekerja & $5(15,2 \%)$ & $7(21,2 \%)$ & $12(36,4 \%)$ \\
Total & $8(24,2 \%)$ & $25(75,8 \%)$ & $33(100 \%)$ \\
\hline
\end{tabular}

Umur berhubungan dengan struktur organ, fungsi faaliah, komposisi biokimiawi termasuk sistem hormonal seorang wanita. Perbedaan fungsi faaliah, komposisi biokimiawi, dan system hormonal pada suatu periode umur menyebabkan perbedaan pada kontrasepsi yang dibutuhkan. (Lontaan, 2014) Berdasarkan hasil penelitian diketahui bahwa sebagian besar responden menggunakan kontrasepsi Non MKJP pada umur 21-35 tahun sebesar 57,6\%. Dan responden yang berumur 21-35 tahun yang memilih kontrasepsi MKJP lebih banyak persentasenya sebesar $15,2 \%$ dibandingkan responden yang berumur $>35$ tahun yang memilih kontrasepsi MKJP $(9,1 \%)$. Masa kehamilan dan persalinan lebih baik pada usia dibawah 30 tahun, sehingga metode kontrasepsi yang dianjurkan adalah kontrasepsi yang mempunyai efektivitas tinggi dan dapat 
mengembalikan kesuburan dengan cepat karena masih ada harapan untuk melahirkan dan punya anak lagi. (Fitrianingsih, 2016) Banyak wanita postpartum memiliki faktor risiko tambahan yang meningkatkan risiko tromboemboli vena, misalnya umur diatas 35 tahun, merokok, atau melahirkan secara caesar. Hal-hal tersebut dapat mempengaruhi penentuan penggunaan kontrasepsi oleh karena kontrasepsi hormonal kombinasi (estrogen dan progestin) memiliki efek samping yang bisa meningkatkan risiko tromboemboli pada wanita usia produktif. (Purwoastuti, 2015) Hasil penelitian ini didukung oleh penelitian Anita bahwa Hubungan umur dengan pemilihan jenis kontrasepsi yang menunjukkan ada hubungan antara umur dengan pemilihan jenis kontrasepsi. Umur hubungannya dengan pemakaian kontrasepsi berperan sebagai faktor intrinsik. (Lontaan, 2014) Hasil penelitian ini berbeda dengan Adrianasti bahwa Hasil uji chi square menunjukkan nilai $\mathrm{p}=0,567$, sehingga tidak terdapat hubungan antara umur dengan pemilihan alat kontrasepsi. (Preputri, 2014) Menurut asumsi peneliti bahwa penggunaan metode kontrasepsi tidak selalu berhubungan dengan umur, namun dapat dikaitkan dengan cocok atau tidaknya responden dengan metode tersebut dan juga berdasarkan pendapatan keluarga (ekonomi). Penghasilan atau pendapatan seseorang sangat berpengaruh terhadap pemilihan alat kontrasepsi, ini disebabkan oleh mahalnya alat kontrasepsi yang digunakan untuk ber-KB, sehingga mereka memilih alat kontrasepsi yang lebih murah. (Darmawati, 2011) Hasil penelitian juga menunjukkan bahwa responden dengan umur risiko tinggi yakni lebih dari 35 tahun sebagian besar memilih kontrasepsi Non MKJP (15,2\%). Berdasarkan Survei Demografi dan Kesehatan Indonesia tahun 2012, suntik dan pil adalah cara KB modern yang paling diketahui oleh masyarakat di semua golongan usia, termasuk pada usia risiko tinggi di atas 35 tahun. Kedua jenis kontrasepsi tersebut dinilai kurang efektif untuk mencegah kehamilan. Jenis kontrasepsi yang efektif untuk mencegah kehamilan bagi wanita risiko tinggi adalah MJKP seperti AKDR, sterilitas wanita dan sterilitas pria. (Kemenkes RI, 2013)

Responden yang berpendidikan tinggi (3\%), sedang $(36,4 \%)$ dan rendah $(36,4 \%)$ sebagian besar menggunakan kontrasepsi Non MKJP. Pendidikan berarti bimbingan yang diberikan seseorang kepada orang lain terhadap sesuatu hal agar mereka dapat memahaminya. Tidak dapat dipungkiri bahwa semakin tinggi pendidikan seseorang, maka semakin mudah pula mereka menerima informasi. Pada akhirnya, makin banyak pula pengetahuan yang dimilikinya, sebaliknya jika seseorang memiliki tingkat pendidikan yang rendah, maka akan menghambat perkembangan sikap seseorang terhadap penerimaan, informasi dan nilai-nilai yang baru dipekenalkan. (Ayunda, 2013) Berdasarkan hasil penelitian diketahui bahwa sebagian besar responden menggunakan Non MKJP pada pendidikan sedang dan rendah masing-masing sebesar 36,4\%. Hasil penelitian ini didukung oleh penelitian Ayunda bahwa hasil uji statistik didapatkan nilai $\mathrm{P}$ value (0.037) berarti ada hubungan antara pendidikan dengan pemilihan metode kontrasepsi oleh PUS Di Desa Peunyerat Kecamatan Banda Raya Banda Aceh. (Ayunda,2013) Hubungan antara pendidikan dengan pola pikir, persepsi dan perilaku masyarakat memang sangat signifikan, dalam arti bahwa semakin tinggi tingkat pendidikan seseorang semakin rasional dalam pengambilan berbagai 
keputusan. Peningkatan tingkat pendidikan akan menghasilkan tingkat kelahiran yang rendah karena pendidikan akan mempengaruhi persepsi negatif terhadap nilai anak dan akan menekan adanya keluarga besar. (Lontaan,2014) Hasil penelitian ini berbeda dengan Adrianasti bahwa hasil uji statistik, diperoleh nilai Fisher's Exact Test=0,573, karena hasil uji yang diperoleh $>0,05$ maka H0 diterima. Hal ini berarti tidak ada hubungan antara pendidikan terakhir responden dengan pemilihan alat kontrasepsi. (Preputri, 2014) Keputusan akseptor KB tidak hanya dipengaruhi oleh pendidikan yang tinggi dan juga tidak menjamin pengetahuan yang baik. Jadi tingkat pendidikan baik tinggi, sedang ataupun rendah tidak dapat menentukan pemilihan metode keluarga berencana yang digunakan oleh pasangan usia subur. Hal ini dapat dikaitkan bahwa peserta KB sudah mengetahui informasi dan manfaat metode kontrasepsi tersebut. (Preputri, 2014)

Berdasarkan hasil penelitian menunjukkan bahwa sebagian besar responden bekerja $(63,6 \%)$. Responden yang tidak bekerja paling banyak memilih kontrasepsi MKJP (15,2\%) dibandingkan responden yang bekerja memilih kontrasepsi MKJP (9,1\%). Berdasarkan penelitian Monika dan Felita menunjukkan bahwa pekerjaan istri tidak mempengaruhi pemilihan metode kontrasepsi pada Wanita Usia Subur (WUS) di Desa Salassae. (Farid, 2017) Pekerjaan, pendapatan keluarga, kekayaan, pengeluaran atau anggaran dan harga makanan merupakan faktor-faktor yang mempengaruhi tingkat ekonomi. Akseptor yang memiliki tingkat ekonomi tinggi akan lebih mampu memilih kontrasepsi efektif. Kemampuan wanita atau pasangan suami istri secara lebih efektif dalam keluarga berencana dapat meningkat atau terhambat oleh status ekonomi. Dikatakan tingkat ekonomi tinggi bila memiliki pendapatan diatas UMR (Upah minimum regional) dan sebaliknya. (Diyah, 2013) Hasil penelitian ini tidak sejalan dengan penelitian Fitrianingsih bahwa tingkat signifikansi status pekerjaan 0,025 (alpa<0,005) yang artinya pekerjaan mempengaruhi pemilihan metode kontrasepsi di Puskesmas Gading Kecamatan Tambaksari Surabaya terhadap suatu pekerjaan. Wanita bekerja dengan aktivitas fisik yang tinggi seperti bersepeda, mengangkat barang, berjalan naik turun tangga atau sejenisnya, kemungkinan tidak akan menggunakan MKJP seperti AKDR dan AKBK dengan alasan takut lepas dan khawatir akan mengganggu pekerjaan atau menimbulkan nyeri saat bekerja. (Fitrianingsih, 2016) Faktor dalam memilih metode kontrasepsi yaitu faktor pasangan, faktor kesehatan dan faktor metode kontrasepsi (efektivitas, efek samping minor, kerugian, komplikasi dan biaya). Pilihan kontrasepsi secara rasional pada dasarnya merupakan pilihan klien secara sukarela tanpa adanya unsur paksaan, yang didasarkan pada pertimbangan secara rasional dari sudut tujuan atau teknis penggunaan, kondisi kesehatan medis, dan kondisi sosial ekonomi dari masing-masing pasangan. (Pradini, 2013)

Metode kontrasepsi yang digunakan berdasarkan hasil penelitian sebagian besar memilih kontrasepsi Non MKJP (75,8\%). Salah satu hal yang dapat mempengaruhi peserta KB lebih memilih kontrasepsi Non MKJP karena sikap akseptor yang cenderung merasa cocok, praktis dan murah. (Septalia, 2016) Kontrasepsi pasangan usia subur akan dipengaruhi oleh jumlah anak yang dimiliki. Pasangan usia subur yang memiliki jumlah anak hidup sedikit cenderung 
menggunakan Non MKJP yang efektivitasnya rendah, sedangkan pada pasangan dengan jumlah anak banyak terdapat kecenderungan menggunakan MKJP yang efektivitasnya tinggi. Kontrasepsi MKJP umumnya digunakan pada ibu yang berumur tua 30 tahun atau lebih (relative tua), sementara Kontrasepsi Non MKJP umumnya digunakan wanita berumur kurang dari 30 tahun (relatif muda). (Fitrianingsih, 2016).

Jenis-jenis kontrasepsi yang digunakan responden berdasarkan hasil penelitian sebagian besar Suntik (54,6\%). Suntikan kontrasepsi yang diberikan setiap 3 bulan sekali mengandung hormone progesterone yang menyerupai hormon progesterone yang diproduksi wanita selama 2 minggu pada setiap awal siklus haid. Hormon tersebut mencegah wanita untuk melepaskan sel telur sehingga memberikan efek kontrasepsi. Banyak klinik yang kesehatan yang menyarankan penggunaan kondom pada minggu pertama saat suntik KB. Sekitar 3 dari 100 orang yang menggunakan KB suntik dapat mengalami kehamilan pada tahun pertama pemakaiannya. (Purwoastuti,2015) Penelitian ini didukung oleh Monika bahwa seluruh metode kontrasepsi yang dipilih oleh WUS di Desa Salassae adalah metode kontrasepsi modern atau efektif. Adapun metode kontrasepsi yang mayoritas digunakan adalah suntik. (Farid, 2017) Hal ini sejalan dengan data Profil Keluarga Indonesia Tahun 2017, sebagian besar akseptor KB aktif memilih suntikan dan pil lebih dari $80 \%$ dibanding metode lainnya. Padahal suntik dan pil merupakan metode kontrasepsi jangka pendek sehingga tingkat efektivitas suntikan dan pil dalam pengendalian kehamilan lebih rendah dibandingkan jenis kontrasepsi lainnya (BKKBN, 2018) Beberapa alasan menggunakan suntik karena menganggap metode suntik praktis, sederhana, murah dan tidak membutuhkan pemakaian setiap hari atau setiap akan bersenggama. (Farid, 2017) Selain itu kontrasepsi 3 bulan aman digunakan untuk ibu menyusui. (Purwoastuti, 2015) Pil kontrasepsi dapat berupa pil kombinasi (berisi hormon estrogen dan progesterone) ataupun hanya berisi progesterone saja. Pil kontrasepsi bekerja dengan cara mencegah terjadinya ovulasi dan penebalan dinding rahim. Apabila pil kontrasepsi ini digunakan secara tepat maka angka kejadian kehamilannya hanya 3 dari 1000 wanita. Disarankan penggunaan kontrasepsi lain (kondom) pada minggu pertama pemakaian pil kontrasepsi. (Purwoastuti,2015) Berdasarkan hasil penelitian responden yang menggunakan kontrasepsi pil sebesar $(12,1 \%)$. Masyarakat cenderung memilih pil KB karena efektif dan reversible, mudah diperoleh dan jarang menimbulkan efek samping yang serius. (Farid, 2017)

Berdasarkan hasil penelitian menunjukkan penggunaan kontrasepsi AKDR $(12,1)$, AKBK (12\%). Alat Kontrasepsi Dalam Rahim (AKDR) merupakan alat kecil berbentuk seperti huruf $\mathrm{T}$ yang lentur dan diletakkan di dalam rahim untuk mencegah kehamilan. Efek kontrasespsi didapatkan dari lilitan tembaga yang ada di badan AKDR. Alat kontrasepsi ini merupakan salah satu kontrasepsi yang paling banyak digunakan di dunia. Efektivitas AKDR sangat tinggi sekitar 99,299,9\%, tetapi AKDR tidak memberikan perlindungan bagi penularan penyakit menular seksual. Disarankan untuk memeriksa keberadaan benang tersebut setiap selesai haid supaya posisi AKDR dapat diketahui. (Purwoastuti,2015) Alat Kontrasepsi Bawah Kulit (AKBK) merupakan alat kontrasepsi yang berbentuk 
batang dengan panjang sekitar $4 \mathrm{~cm}$ yang di dalamnya terdapat hormon progesterone, alat ini kemudia dimasukkan ke dalam kulit di bagian lengan atas. Hormon tersebut kemudian dilepaskan secara perlahan dan dapat efektif sebagai kontrasepsi selama 3 tahun. Sama seperti kontrasepsi suntik, maka disarankan penggunaan kondom untuk minggu pertama sejak pemasangan AKBK. (Purwoastuti,2015) Metode AKDR dan AKBK kurang diminati oleh masyarakat. Kontrasepsi AKBK dianggap kurang aman karena akan menimbulkan efek samping. Demikian pula dengan kontrasepsi AKDR, karena prosedur yang cukup rumit, harus dikerjakan oleh tenaga medis terlatih dan terkesan tabu karena alatnya dimasukkan ke dalam kemaluan akseptor, sehingga masyarakat takut untuk menggunakannya. (Farid, 2017)

Metode Amenore laktasi dan kondom merupakan metode kontrasepsi sederhana. Metode Amenore Laktasi (MAL) adalah metode kontrasepsi sementara yang mengandalkan pemberian Air Susu Ibu secara eksklusif, artinya hanya diberikan ASI saja tanpa tambahan makanan dan minuman lainnya. MAL dapat dikatakan sebagai metode keluarga berencana alamiah (KBA) atau natural family planning, apabila tidak dikombinasikan dengan metode kontrasepsi lain. (Purwoastuti,2015) Kondom merupakan jenis kontrasepsi penghalang mekanik. Kondom mencegah kehamilan dan infeksi penyakit kelamin dengan cara menghentikan sperma untuk masuk ke dalam vagina. Kondom pria dapat terbuat dari bahan latex (karet), polyurethane (plastic), sedangkan kondom wanita terbuat dari polyurethane. Pasangan yang mempunyai alergi terhadap latex dapat menggunakan kondom yang terbuat dari polyurethane. Efektivitas kondom pria antara 85-98\% sedangkan efektivitas kondom wanita antara 79-95\%. Harap diperhatikan bahwa kondom pria dan wanita sebaiknya jangan digunakan secara bersamaan. (Purwoastuti,2015)

Untuk pemilihan metode kontrasepsi, keamanan penggunaan menjadi hal yang utama yang harus diperhatikan khususnya untuk wanita, termasuk wanita dalam masa postpartum. Dalam penilaian kesehatan, seorang wanita harus mempertimbangkan karakteristik (umur, pendidikan, pekerjaan, status ekonomi) serta kondisi medis yang dimiliki wanita tersebut. Selain itu, wanita yang telah memiliki jumlah anak yang cukup dapat dipertimbangkan kontrasepsi mantap. Kontrasepsi setelah persalinan cukup penting untuk menjaga kesehatan ibu dan anak, dan edukasi yang diberikan berfokus kepada pilihan kontrasepsinya serta tingkat keamanan dalam pemakaian metode kontrasepsi tersebut. (Purwoastuti, 2015) Faktor sosial ekonomi dan pendidikan juga turut mempengaruhi pengetahuan seseorang dalam menentukan jenis kontrasepsi, yang mempunyai pendapatan tcukup dan pendidikan tinggi akan mempunyai pengetahuan yang relatif tinggi dan kemudahan dalam memilih metode kontrasepsi yang sesuai dibandingkan dengan akseptor yang mempunyai pendapatan rendah berkaitan dengan jenis kontrasepsi yang digunakan tersebut terdapat kekurrangan dan kelebihan serta efek samping masing-masing alat. (Pradini, 2013) 


\section{SIMPULAN DAN SARAN}

\section{Simpulan}

Hasil penelitian berjudul Studi Deskriptif Penggunaan Metode Kontrasepsi di PMB Anik Setyowati Ngesrep Ngemplak Boyolali didapatkan sebagian besar responden berumur 20-35 tahun sebanyak 24 responden $(72,7 \%)$; dengan pendidikan Sedang dan rendah, masing-masing sebanyak 16 responden (48,5\%); bekerja sebanyak 21 responden $(63,6 \%)$. Sebagian besar responden menggunakan Non Metode Kontrasepsi Jangka Panjang (Non MKJP) sebanyak 25 responden (75,8\%), yakni Kontrasepsi Suntik sebanyak 18 responden (54,6\%). Simpulan: Sebagian besar responden berumur 21-35 tahun, berpendidikan sedang dan rendah, bekerja, menggunakan metode kontrasepsi Non MKJP yakni Suntikan kontrasepsi.

\section{Saran}

Bagi Institusi STIKES Mamba'ul 'Ulum Surakarta bahwa dari hasil penelitian ini diharapkan STIKES Mamba'ul 'Ulum Surakarta khususnya program studi DIII Kebidanan meningkatkan fasilitas penelitian dosen dengan sejawat dan ataupun mahasiswa. Saran bagi responden lebih memperhatikan faktor kesehatan disamping usia dalam penentuan metode keluarga berencana yang akan diikuti serta melibatkan pasangan dalam memilih kontrasepsi yang sesuai. Bagi Peneliti Selanjutnya diharapkan hasil penelitian ini dapat memberikan masukan bagi peneliti selanjutnya untuk meneliti tentang pemilihan kontrasepsi dilihat dari segi kesehatan dan tingkat ekonomi.

\section{DAFTAR PUSTAKA}

Anggraeni, Y, Martini. 2012. Pelayanan Keluarga Berencana. Yogyakarta: Rohima Press

Ayunda, SS. 2013. Faktor-faktor yang Berhubungan Dengan Pemilihan Metode Kontrasepsi oleh PUS di Desa Peunyerat Kecamatan Banda Raya Banda Aceh. $\quad$ https://simtakp.uui.ac.id/dockti/SAMIRA_SRI_AYUNDAskripsi.pdf

BKKBN. 2018. Jurnal Keluarga :Informasi Kependudukan , KB dan Pembangunan Keluarga. edisi ke 1 2018. Program KKBPK dalam SDKI $2017 \quad 27 . \quad$ https://www.bkkbn.go.id/pocontent/uploads/Final.JK.Edisi.Ketiga.2017.Min.pdf

Darmawati. 2011. Faktor-Faktor Yang Mempengaruhi Wanita Usia Subur Memilih Kontrasepsi Suntik. Idea Nursing Jurnal Volume II Nomor 3. http://www.jurnal.unsyiah.ac.id/INJ/article/viewFile/6504/5332

Farid, MF, Felita AG. 2017. Faktor-Faktor Yang Mempengaruhi Pemilihan Metode Kontrasepsi Pada Wanita Usia Subur (WUS) di Desa Salassae Kecamatan Bulukumba Kabupaten Bulukumba Provinsi Sulawesi Selatan. JST Kesehatan Oktobre 2017 Volume 7 Nomer 4 hal: 381-388. 
http://pasca.unhas.ac.id/jurnal/files/0d8369b82684e192382269a48aca888 6.pdf

Fitrianingsih, AD, Soenarnatalina M. 2016. Faktor Sosiodemografi yang Mempengaruhi Pemilihan Metode Kontrasepsi. Jurnal Biometrika dan Kependudukan Volume 5 Nomer 1 Juli 2016 hal:10-18. https://ejournal.unair.ac.id/JBK/article/download/5790/3701

Kabupaten Boyolali. 2016. Profil Kesehatan Kabupaten Boyolali 2015. http://www.depkes.go.id/resources/download/profil/PROFIL_KAB_KOT A_2015/3309_Jateng_Kab_Boyolali_2015.pdf,

Setiasih, Sri, Bagus W, Tinuk I. 2016. Analisis Faktor-faktor yang Mempengaruhi Pemilihan Metode Kontrasepsi Jangka Panjang (NKJP) pada Wanita Pasangan Usia SUbur (PUS) di Kabupaten Kendal Tahun 2013. Jurnal Promosi Kesehatan Indonesia Volume 11 Nomor 2 Agustus 2016. https://ejournal.undip.ac.id/index.php/jpki/article/download/19002/13247

Kemenkes RI. 2013. Situasi Keluarga Berencana di Indonesia. Buletin Jendela Data dan Informasi Kesehatan Semester II 2013 ISSN 2088-270x. http://www.depkes.go.id/download.php?file=download/pusdatin/buletin/ buletin-kespro.pdf.

Kemenkes RI. 2018. Profil Kesehatan Indonesia Tahun 2017. http://www.depkes.go.id/resources/download/pusdatin/profil-kesehatanindonesia/Profil-Kesehatan-Indonesia-tahun-2017.pdf

Lontaan, A, Kusmiyati, Robin D. 2014. Faktor-Faktor Yang Berhubungan Dengan Pemilihan Kontrasepsi Pasangan Usia Subur Di Puskesmas Damau Kabupaten Talaud. Jurnal Ilmiah Bidan Volume 2 Nomor 1 Januari-Juni 2014. https://media.neliti.com/media/publications/91154-IDfaktor-faktor-yang-berhubungan-dengan-pe.pdf

Perputri, A, Zulkifli A, Ida LMT. 2014. Faktor yang Berhubungan Dengan Pemilihan Alat Kontrasepsi Pada Wanita Di Wilayah Pesisir Kecamatan Bantaeng Kabupaten Bantaeng. http://repository.unhas.ac.id/bitstream/handle/123456789/10656/ANDRI ANASTI\%20PREPUTRI\%20K11110008.pdf;sequence=1

Pradini, DI, Yhona P, Dedi MP. 2013. Tingkat Ekonomi Keluarga Berhubungan Dengan Pemilihan Alat Kontrasepsi di Dukuh Manukan Sendangsari Pajangan Bantul. Jurnal Ners dan Kebidanan Indonesia Volume I Nomor 2 Tahun 2013 hal:55-60. https://ejournal.almaata.ac.id/index.php/JNKI/article/download/238/230

Purwoastuti, E, Elisabeth SW. 2015. Panduan Materi Kesehatan Reproduksi dan Keluarga Berencana. Yogyakarta: Pustaka Baru.

Septalia, R, Nunik P. 2016. Faktor Yang Mempengaruhi Pemilihan Metode Kontrasepsi. Jurnal Biometrika dan Kependudukan Volume 5 Nomer 2 Desember 2016 hal:91-98. https://ejournal.unair.ac.id/JBK/article/view/5828/3731 